\title{
ANALISIS WAKTU DAN BIAYA DENGAN METODE CRASH DURATION PADA KETERLAMBATAN PROYEK PEMBANGUNAN JEMBATAN SEI HANYU KABUPATEN KAPUAS
}

\author{
Wateno Oetomo ${ }^{(1)}$, Priyoto $^{(2)}$, Uhad $^{(3)}$ \\ Pegawai Negeri Sipil \\ Balai Besar Pelaksanaan Jalan Nasional VII \\ Direktorat Jenderal Bina Marga Kementerian Pekerjaan Umum dan Perumahan Rakyat
}

\begin{abstract}
ABSTRAK
Dalam melakukan analisa perbandingan biaya percepatan dengan waktu percepatan digunakan metode TCTO (Time Cost Trade Off). Analisa dilakukan dengan cara memamfaatkan/mempersingkat (crashing) waktu pelaksanaan dengan menggunakan alternatif menambah jam kerja (lembur) selama 3 jam . Dengan menerapkan analisa TCTO, pelaksanaan proyek pembangunan Jembatan Sei Hanyu ini yang durasinya setelah dilakukan perhitungan menggunakan metode crash duration, didapatkan bahwa waktu yang diperlukan untuk mempercepat pelaksanaan pembangunan jembatan Sei Hanyu Kabupaten Kapuas selama 1038 hari kalender (148 minggu), dapat dipercepat 44 hari dari perencanaan semula 1082 hari kalender (155 minggu).

Dengan adanya percepatan penyelesaian pembangunan jembatan Sei Hanyu Kabupaten Kapuas, diperlukan tambahan biaya sebesar Rp 175.160.710,43 dengan penambahan biaya (cost slope) sebesar Rp 3.980.925,24 per hari selama 44 hari, sehingga biaya optimal yang diperlukan untuk mempercepat pelaksanaan pembangunan jembatan Sei Hanyu Kabupaten Kapuas adalah sebesar Rp 45.102.729.928,11 yang semula direncanakan sebesar Rp 44.927.569.217,68
\end{abstract}

Kata kunci : Metode Crash Duration, jembatan, cost slope 
Analisis Waktu Dan Biaya Dengan Metode Crash...Wateno ${ }^{(\mathbf{1})}$, Priyoto ${ }^{(\mathbf{2})}$, Uhad ${ }^{(\mathbf{3})}$

\section{PENDAHULUAN}

\section{Latar Belakang}

Pada proses pelaksanaan proyek, selalu terkait dengan biaya, waktu dan kualitas dari konstruksinya. Tahap awal dalam proyek konstruksi adalah tahap perencanaan. Perencanaan kegiatankegiatan proyek merupakan masalah yang sangat penting karena perencanaan kegiatan merupakan dasar untuk proyek bisa berjalan dan agar proyek yang dilaksanakan dapat selesai dengan waktu yang optimal. Pada proses pelaksanaan suatu proyek konstruksi, akan selalu dipengaruhi oleh kegiatan sebelumnya yaitu mulai dari ide dan perencanaan yang telah direncanakan.

Dalam pembangunan suatu proyek konstruksi, pengendalian biaya proyek merupakan hal yang penting dalam proses pengelolaan biaya proyek. Dalam kegiatan suatu proyek akan banyak didapati masalah seperti penggunaan material yang boros, tenaga kerja yang kurang terampil dan waktu penyelesaian proyek yang tidak tepat waktu sehingga menyebabkan pemborosan biaya yang tidak sesuai perencanaan. Perencanaan, pengendalian biaya dan waktu merupakan bagian dari manajemen proyek konstruksi secara keseluruhan. Selain penilaian dari segi kualitas atau mutu, prestasi suatu proyek dapat pula dinilai dari segi biaya dan waktu. Biaya yang telah dikeluarkan dan waktu yang digunakan dalam menyelesaikan suatu pekerjaan harus diukur secara kontinyu penyimpangannya terhadap rencana. Adanya penyimpangan biaya dan waktu yang signifikan memberikan indikasi pengelolaan proyek yang kurang baik.

Suatu proyek akan dianggap berhasil apabila produk yang dihasilkan sesuai standar mutu, waktu pelaksanaan dan batas anggaran yang telah ditetapkan, terkadang ada kalanya terjadi penyimpangan antara ketiga aspek tersebut. Waktu dan biaya masih dapat dioptimalisasikan lagi, yang dimaksud dengan pengoptimalan biaya dalam hal ini adalah antara perbandingan biaya dan waktu yang terbaik, dimana dapat menghasilkan biaya yang minimum dengan waktu minimum pula, sedangkan untuk mutu merupakan mutlak tidak bisa dirubah dan harus sesuai dengan perencanaan.

Selain itu, waktu sangatlah penting dalam pelaksanaan proyek. Dengan adanya waktu, dapat ditentukan kapan suatu pekerjaan berakhir. Bahkan juga dapat diketahui boros atau efisien suatu pekerjaan jika tidak dapat memanajemen dengan baik. Pada tahapan perencanaan proyek, diperlukan adanya estimasi durasi waktu pelaksanaan proyek. Realita di lapangan menunjukkan bahwa waktu penyelesaian sebuah proyek bervariasi, akibatnya perkiraan waktu penyelesaian suatu proyek tidak bisa dipastikan akan dapat ditepati. Tingkat ketepatan estimasi waktu penyelesaian proyek ditentukan oleh tingkat ketepatan perkiraan durasi setiap kegiatan di dalam proyek. Selain ketepatan perkiraan waktu, penegasan hubungan antar kegiatan suatu proyek juga diperlukan untuk perencanaan suatu proyek. Dalam mengestimasi waktu dan biaya di sebuah proyek maka diperlukan optimalisasi.

Salah satu jembatan yang ada di Kabupaten Kapuas adalah jembatan Sei Hanyu. Dimana pembangunan jembatan ini untuk meningkatkan sarana transportasi darat sehingga diharapkan dapat membawa kemajuan diberbagai bidang.

Pada data awal perencanaan proyek, waktu penyelesaian proyek selama 1082 hari kalender dengan nilai kontrak sebesar Rp 58,141 Milyar. Dari data tersebut perlu dilakukan penelitian analisis waktu dan biaya dengan Metode Time Cost Trade Off (TCTO) pada proyek pembangunan Jembatan Sei Hanyu, sehingga ditinjau secara ekonomis, proyek tersebut dilaksanakan secara efektif dan efisien.

\section{Rumusan Masalah}

Dari latar belakang tersebut dapat dibuat rumusan masalah sebagai berikut :

1. Berapa besar perubahan waktu dan biaya pada proyek pembangunan jembatan Sei Hanyu Kabupaten kapuas dengan Metode Time Cost Trade Off Analysis?

2. Berapa besar efisiensi biaya percepatan akibat keterlambatan pelaksanaan pekerjaan?

\section{Tujuan Penelitian}

Tujuan dari penelitian adalah :

1. Untuk menetukan besarnya perubahan waktu dan biaya dengan metode Time Cost Trade Off Analysis.

2. Untuk menentukan efisiensi biaya percepatan akibat keterlambatan pelaksanaan pekerjaan.

\section{Manfaat Penelitian}

Manfaat yang diperoleh dari pembangunan jembatan Sei Hanyu Kabupaten Kapuas adalah sebagai berikut: 
Analisis Waktu Dan Biaya Dengan Metode Crash...Wateno ${ }^{(\mathbf{1})}$, Priyoto ${ }^{(\mathbf{2})}$, Uhad ${ }^{(\mathbf{3})}$

1. Bagi Perusahaan

a. Mengetahui gambaran yang benar tentang proses perencanaan proyek.

b. Mempunyai panduan tertulis yang berguna untuk menganalisa proses dan tindakan yang diambil sehingga dapat mengoptimalkan dalam pengendalian waktu dan biaya.

2. Sebagai literature dan masukan bagi mahasiswa yang berminat dengan permasalahan ini dalam meneliti pembangunan Jembatan.

3. Bagi Peneliti, penelitian ini bermanfaat untuk menambah wawasan dan sarana aplikasi teori yang diterima selama menempuh kuliah dengan data empiris yang ada dilapangan serta pengalaman penelitian khususnya tentang pembangunan jembatan dengan Crash Duration.

\section{Batasan dan Ruang Lingkup Penelitian}

Batasan dan ruang lingkup penelitian ini adalah sebagai berikut:

1. Analisa kinerja proyekdilihat dari sudut pandang kontraktor pelak-sana.

2. Batasan masalah pada penelitian ini meliputi biaya dan waktu, pembangunan jembatan Sei hanyu Kabupaten Kapuas dari persiapan sampai finishing.

3. Dengan menggunakan metode Time Cost Trade Off (TCTO) atau Pertukaran Biaya dan Waktu.

4. Sotware yang digunakan untuk menganalisa jaringan kerja adalah Microsoft Excel dan Microsoft Project.

\section{TINJAUAN PUSTAKA}

\section{Penelitian Terdahulu}

1. Ariany Frederika (2010) melakukan penelitian dengan analisis Crash Duration pada proyek pembangunan Super Villa, Peti TengetBandung. Proyek ini mengalami keterlambatan dalam pelaksanaannya. Alternatif percepatan yang dipilih adalah dengan menambah jam kerja, dari satu jam sampai empat jam tanpa adanya penambahan tenaga kerja.

2. Penelitian Teguh Arifmawan Sudharta (2011) bertujuan untuk melakukan optimasi waktu pelaksanaan proyek konstruksi dengan penambahan jam kerja pada proyek Hotel Penin Sula Bay Resort. Proyek ini mengalami keterlambatan sehingga dipilih sebagai objek penelitian. Penambahan jam kerja sebagai alternatif percepatan yang digunakan yaitu dari satu jam sampai tiga jam kerja. Data-data yang diperlukan berupa data sekunder (RAB, daftar analisis harga satuan, daftar upah, dan time schedule).

3. Penelitian Rita Nawangsari Pamungkas dan Rizki Taufik Hidayat (2011) dengan judul Analisis Crash Duration Pada Proyek Konstruksi dengan mengambil studi kasus pada Proyek Pembangunan Gedung Kuliah Bersama Fakultas Teknik Universitas Diponegoro Bantuan Pertamina Tahun 2010, Proyek Pembangunan Embung Tambakboyo Kabupaten Sleman Daerah Istimewa Yogyakarta, dan Proyek Pembangunan Jalan dan Jembatan Lingkar Salatiga (Paket 2). Alternatif yang digunakan adalah penambahan jam kerja (lembur) dan penambahan tenaga kerja dengan tiga asumsi yang digunakan, yaitu crashing $6 \%$, $8 \%$, dan $15 \%$.

4. Penelitian yang dilakukan oleh Jevri Krisanto Lumbanbatu (2013) dengan judul Akselerasi Durasi Proyek Pada Pembangunan Gedung Sekolah Yayasan Pelita Bangsa Yang Berlokasi di Jl.Iskandar Muda Medan. Metode yang digunakan adalah Crash Duration dengan tujuan utama untuk mengetahui jumlah waktu yang dapat dipercepat dan berapa besar biaya yang akan dikeluarkan. Proyek tersebut dipilih sebagai tempat studi penelitian karena mengalami keterlambatan pekerjaan. Langkahlangkah yang dilakukan antara lain menyusun jaringan kerja dengan metode Critical Path Method (CPM), mengidentifikasi jalur kritis dan jalur non kritis dan melakukan analisis perhitungan percepatan waktu dan biaya proyek.

\section{Penjadwalan Proyek}

berikut :

Adapun tujuan penjadwalan adalah sebagai

a. Mempermudah perumusan masalah proyek.

b. Menentukan metode atau cara yang sesuai.

c. Kelancaran kegiatan lebih terorganisir.

d. Mendapatkan hasil yang optimum.

Sedangkan fungsi penjadwalan dalam suatu proyek konstruksi antara lain :

a Menentukan durasi total yang dibutuhkan untuk menyelesaikan proyek.

b Menentukan waktu pelaksanaan dari masingmasing kegiatan.

c Menentukan kegiatan-kegiatan yang tidak boleh terlambat atau tertunda pelaksanaannya dan menentukan jalur kritis.

d Menentukan kemajuan pelaksanaan proyek.

e Sebagai dasar perhitungan cash flow proyek 
f Sebagai dasar bagi penjadwalan sumber daya proyek, seperti tenaga kerja, material, dan peralatan.

g Sebagai alat pengendalian proyek.

Data yang diperlukan adalah :

a. Proyek konstruksi yang akan dilaksanakan.

b. Metode pelaksanaan.

c. Membuat list semua kegiatan yang sudah dilakukan untuk proyek tersebut, serta perkiraan waktu yang diperlukan.

d. Urutan pelaksanaan kegiatan.

e. Ketergantungan pelaksanaan antara kegiatan satu dan lainya.

Mengingat perubahan-perubahan yang selalu terjadi pada saat pelaksanaan, maka beberapa faktor harus diperhatikan untuk membuat jadwal proyek yang cukup efektif, yaitu :

a. Secara teknis, jadwal tersebut bisa dipertanggungjawabkan (technically feasible).

b. Disusun berdasarkan perkiraan / ramalan yang akurat (reliable estimate) dimana perkiraan waktu, sumber daya, serta biayanya berdasarkan kegiatan pada proyek sebelumnya.

c. Sesuai sumber daya yang sesuai.

d. Sesuai penjadawalan proyek lainnya yang menggunakan sumber daya yang sama.

e. Fleksible terhadap perubahan-perubahan, misalnya perubahan pada spesifikasi proyek.

f. Mendetail yang dipakai sebagai alat pengukur hasil yang dicapai dan pengendalian kemajuan proyek.

g. Dapat menampilkan kegiatan pokok kritis.

\section{Jaringan Kerja (Network Planning)}

Proyek dan analisis jaringan kerja adalah serangkaian kegiatan-kegiatan yang bertujuan untuk menghasilkan produk dan hanya dapat dilakukan dalam periode waktu tertentu.

Menurut Sofyan Badri (1997) "Network Planning pada prinsipnya adalah hubungan ketergantungan antara bagian-bagian pekerjaan (Variabel) yang digambarkan dalam diagram network". Dengan demikian diketahui bagian-bagian pekerjaan mana yang harus didahulukan, bila perlu dilembur (tambah biaya), pekerjaan mana yang menunggu selesainya pekerjaan yang lain, pekerjaan yang mana yang tidak perlu tergesa-gesa sehingga alat dan tenaga dapat digeser ketempat lain demi efisiensi.

Sedangkan Menurut Soetomo Kajatmo (1977) "Network Planning" merupakan sebuah alat manjemen yang memungkinkan dapat lebih luas dan lengkapnya perencanaan dan pengawasan suatu proyek". Adapun defenisi proyek itu sendiri adalah suatu rangkaian kegiatan kegiatan (aktifitas) yang mempunyai saat permulaan dan yang harus dilaksanakan serta diselesaikan untuk mendapat tujuan tertentu.

Pengertian lain yang dikemukakan oleh Tubagus Haedar Ali (1995) yaitu Network Planning adalah salah satu model yang digunakan dalam penyelenggaraan proyek yang produknya adalah informasi mengenai kegiatan-kegiatan yang ada dalam network diagram proyek yang bersangkutan.

Tahapan dalam analisis proyek meliputi perencanaan, penjadwalan dan pengontrolan jalannya eksekusi dari semua kegiatan. Tahap ini perencanaan suatu proyek memerlukan pendefenisian yang dapat membedakan jenis dari setiap kegiatan yang yang terlibat didalamnya. Selain itu juga ketetapan prakiraan waktu yang diperlukan untuk memproses setiap kegiatan dalam penegasan hubungan antara kegiatan di suatu proyek. Hubungan antar kegiatan dalam suatu proyek dapat berupa hubungan mendahului, hubungan sejajar dan hubungan didahului. Begitu ketiga hal tersebut terpenuhi maka suatu model network yang sesuai dapat digunakan untuk menganalisis jadwal pelaksanaan dari seluruh kegiatan proyek.

\section{Manfaat Network Planning}

Network planning merupakan teknik perencanaan yang dapat mengevaluasi interaksi antara kegiatan-kegiatan. Manfaat yang dapat dirasakan dari pemakaian analisis network planing adalah sebagai berikut :

1. Dapat mengenali (identifikasi) jalur kritis (critucal part) dalam hal ini adalah jalur elemen yaitu kegiatan yang kritis dalam skala wktu penyelesaian proyek secara keseluruhan.

2. Dapat diketahui secara pasti kesukaran yang akan timbul jauh sebelum terjadinya sehingga dapat diambil tindakan yang presentatif.

3. Mempunyai kemapuan mengadakan perubahanperunahan sumber daya dan memperhatikan efek terhadap waktu selesainya proyek.

4. Sebagai alat komunikasi yang efektif.

5. Memungkinkan tercapainya penyelenggaraan proyek yang lebih ekonomis dipandang dari sudut biaya langsung dan penggunaan sumber daya yang optimum.

6. Dapat dipergunakan untuk memperkirakan efekefek dari hasil yang dicapai suatu kegiatan terhadap keseluruhan rencana. 
Analisis Waktu Dan Biaya Dengan Metode Crash... Wateno ${ }^{(\mathbf{1})}$, Priyoto ${ }^{(\mathbf{2})}$ Uhad $^{(\mathbf{3})}$

\section{Bentuk Network Planning}

Planning.

Notasi dan Simbol-simbol Network

a. $\longrightarrow$ : Arrow / anak panah yang menyatakan aktifitas/kegiatan yaitu suatu kegiatan atau pekerjaan dimana penyelesainnya membutuhkan durasi (jangka waktu tertentu) dan resorces (tenaga, alat, material dan biaya).

Kepala anak panah menjadi pedoman arah tiap kegiatan, dimana panjang dan kemiringan tidak berpengaruh.

b.<smiles>C1CC2CC3CC(C1)C23</smiles>
: Node / Event, yang merupakan lingkaran bulat yang artinya saat peristiwa atau kejadian yaitu pertemuan dari permulaan dan akhir kegiatan.

c. terputus-putus yang menyatakan kegiatan semu yaitu aktifitas yang tidak membutuhkan durasi dan resources.

d. $\longrightarrow$ : Double Arrow / Dobel anak panah yang menunjukkan kegiatan dilintasan kritis (critical path).

\section{Lintasan Kritis (Critical Path)}

Dalam metode critical path, jalur kritis dapat dihitung dengan menghitung total durasi proyek. Langkah-langkah dalam penjadwalan dengan metode Critical Path, adalah sebagai berikut:

1. Menentukan aktivitas individu.

2. Menentukan urutan aktivitas-aktivitas (hubungan keterkaitan antar aktivitas).

3. Menggambar diagram jaringan kerja.

4. Estimasi waktu penyelesaian tiap aktivitas.

5. Identifikasi jalur kritis.

6. Memperbarui diagram Critical Path.

Untuk menentukan lintasan kritis, digunakan program bantu Microsoft Project. Microsoft Project adalah sebuah aplikasi untuk mengelola suatu proyek. Microsoft Project merupakan sistem perencanaaan yang dapat membantu dalam menyusun penjadwalan (scheduling) suatu proyek atau rangkaian pekerjaan. Microsoft Project juga mampu membantu melakukan pencatatan dan pemantauan terhadap penggunaan sumber daya (resource), baik yang berupa sumber daya manusia maupun yang berupa peralatan. Yang dikerjakan oleh Microsoft Project antara lain: mencatat kebutuhan tenaga kerja pada setiap sektor, mencatat jam kerja para pegawai, jam lembur dan menghitung pengeluaran sehubungan dengan ongkos tenaga kerja, memasukkan biaya tetap, menghitung total biaya proyek, serta membantu mengontrol penggunaan tenaga kerja pada beberapa pekerjaan untuk menghindari overallocation (kelebihan beban pada penggunaan tenaga kerja) (Kusrianto, 2008).

Dalam Microsoft Project ada beberapa istilah khusus, antara lain:

1. Task

Task adalah salah satu bentuk lembar kerja dalam Microsoft Project yang berisi rincian pekerjaan sebuah proyek.

2. Duration

Duration merupakan jangka waktu yang diperlukan untuk menyelesaikan suatu pekerjaan.

3. Start

Start merupakan nilai tanggal dimulainya suatu pekerjaan.

4. Finish

Dalam Microsoft Project tanggal akhir pekerjaan disebut finish, yang akan diisi secara otomatis dari perhitungan tanggal mulai (start) ditambah lama pekerjaan (duration).

5. Predecessor

Predecessor merupakan hubungan keterkaitan antara satu pekerjaan dengan pekerjaan lain. Ada hubungan saling ketergantungan antara tugas yang satu dengan tugas lain pada aplikasi Microsoft Project, dikenal 4 (empat) hubungan antartugas, yaitu:

1) Start to Start

Yaitu suatu tugas harus dimulai bersamaan waktunya dengan tugas lain.

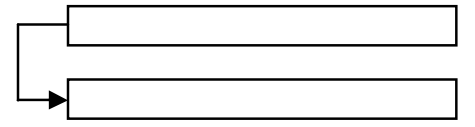

2) Start to Finish

Yaitu suatu tugas baru boleh diakhiri jika tugas lain dimulai.

3) Finish to Start

Yaitu suatu tugas baru boleh dimulai jika tugas pendahulunya telah selesai.

4) Finish to Finish

Yaitu suatu tugas harus selesai bersamaan dengan selesainya tugas yang lain. 
Analisis Waktu Dan Biaya Dengan Metode Crash... Wateno ${ }^{(\mathbf{1})}$, Priyoto ${ }^{(\mathbf{2})}$ Uhad $^{(\mathbf{3})}$

6. Resources

Sumber daya, baik sumber daya manusia maupun material dalam Ms. Project disebut dengan resources.

7. Baseline

Baseline adalah suatu rencana baik jadwal maupun biaya yang telah disetujui dan ditetapkan.

8. Gantt Chart

Gantt chart merupakan salah bentuk tampilan dari Ms. Project yang berupa batang-batang horizontal yang menggambarkan masingmasing pekerjaan beserta durasinya.

9. Tracking

Tracking adalah mengisikan data yang terdapat di lapangan pada perencanaan yang telah dibuat.

\section{Mempercepat Waktu Penye-lesaian Proyek}

Mempercepat penyelesaian waktu proyek adalah suatu usaha menyelesaikan proyek lebih awal dari waktu penyelesaian dalam keadaan normal. Proses mempercepat waktu penyelesaian proyek dinamakan Crash Program. Dengan diadakannya percepatan proyek ini, akan terjadi pengurangan durasi kegiatan pada kegiatan yang akan diadakannya crash program. Akan tetapi, terdapat batas waktu percepatan (crash duration) yaitu suatu batas dimana dilakukan pengurangan waktu melewati batas waktu ini akan tidak efektif lagi.

Durasi percepatan (crashing) maksimum suatu aktivitas adalah durasi tersingkat untuk menyelesaikan suatu aktivitas yang secara teknis masih mungkin dengan asumsi sumber daya bukan merupakan hambatan (Soeharto, Iman, 1999).

Konsekuensi dari percepatan proyek atau crashing program adalah meningkatnya biaya langsung (direct cost)

\section{Pertukaran Biaya Dan Waktu ( Time Cost Trade Off )}

Penyelesaian aktivitas didalam suatu proyek memerlukan penggunaan sejumlah sumber daya minimum dan waktu penyelesaian yang optimum, sehingga aktivitas akan dapat diselesaikan dengan biaya normal dan durasi normal. Jika suatu saat diperlukan penyelesaian yang lebih cepat, penambahan sumber daya memungkinkan pengurangan durasi proyek dengan melakukan kompresi durasi aktivitas, harus tetap diupayakan agar penambahan dari segi biaya seminimal mungkun. Pengendalian biaya yang dilakukan adalah biaya langsung, karena biaya inilah yang akan bertambah apabila dilakukan pengurangan durasi. Kompresi ini dilakukan pada aktivitas-aktivitas yang berada pada lintasan kritis dan mempunyai cost slope terendah. Percepatan durasi dapat dilaksanakan dengan cara penambahan jumlah tenaga kerja, penambahan jam kerja ( lembur), penambahan atau penggantian peralatan yang lebih produktif, dan penggantian material yang dapat membuat pekerjaan lebih cepat tanpa mengurangi mutu serta penyempurnaan metode pelaksanaan konstruksi.

\section{Metode Crash Duration}

Dalam penyusunan schedule suatu proyek konstruksi biasanya tidak langsung dihasilkan suatu schedule yang ideal, salah satu tujuan penyusunan schedule adalah menghasilkan schedule yang realistis berdasarkan estimasi yang wajar.Banyak terjadi penetapan durasi suatu proyek ditetapkan oleh pemilik proyek tanpa mempertimbangkan jenis kegiatan dan kompleksnya pekerjaan. Hal ini membuat para scheduler melakukan penyesuaian durasi dari tiap pekerjaan agar dapat memenuhi permintaan pemilik proyek, sehingga dapat menghasilkan schedule yang tidak efisien dan kadangkadang tidak realistis, seperti terjadinya shift dalam pelaksanaan kerja, kerja lembur atau mengerahkan tenaga kerja dalam kelompok yang besar. Proses crashing adalah dengan mereduksi suatu pekerjaan yang akan berpengaruh terhadap waktu penyelesaian proyek. Crashing adalah suatu proses yang disengaja, sistematis dan analitik dengan cara melakukan pengujian dari semua kegiatan dalam suatu proyek yang dipusatkan pada kegiatan yang berada dijalur kritis. Proses crashing dengan cara melakukan perkiraan dari variable cost dalam menentukan pengurangan durasi yang maksimal dan paling ekonomis dari suatu kegiatan yang masih mungkin untuk direduksi.

Dalam melaksanakan suatu kegiatan proyek konstruksi terdapat berbagai pekerjaan, terutama dalam proyek gedung jenis kegiatan tersebut dapat mencapai puluhan, ratusan atau bahkan ribuan item kegiatan. Kegiatan dalam suatu proyek dapat dipercepat dengan berbagai cara (Ervianto, 2004), yaitu :

1. Mengadakan shift pekerjaan.

Membagi jumlah tenaga kerja menjadi beberapa kelompok yang bekerja secara bergantian, yang bertujuan untuk meminimalisasi turunnya 
kemampuan tenaga kerja akibat kerja lembur yang terlalu lama.

2. Memperpanjang waktu kerja (lembur)

Kerja lembur adalah penambahan jam kerja dari waktu yang ditetapkan untuk setiap harinya. Perhitungan upah lembur tenaga kerja di Indonesia menunjuk kepada surat keputusan Menteri Tenaga Kerja No : KEP-72/MEN/84 tentang dasar upah lembur.

3. Dengan menggunakan alat bantu yang lebih produktif.

4. Menambah jumlah pekerja.

Dengan menambah jumlah pekerja, maka waktu pelaksanaan akan lebih singkat.

Hal yang perlu diperhatikan antara lain :

a. Kapasitas lahan proyek untuk menampung sejumlah pekerja.

b. Produktifitas pekerja, untuk besarnya nilai produktivitas dapat diperoleh dari pengalaman.

c. Efektifitas dalam pengawasan tenaga kerja.

d. Keamanan tenaga kerja.

e. Biaya upah tenaga kerja.

Jumlah tenaga kerja sangat berhubungan dengan nilai produktivitas tenaga kerja agar sesuai dengan waktu yang diperlukan.

5. Dengan menggunakan material yang dapat lebih cepat penggunaannya.

Hal yang perlu diperhatikan :

a. Produktivitas alat tambahan tersebut.

b. Perlu tidaknya tenaga ahli untuk menangani alat tersebut.

c. Harga, biaya, dan perawatan.

6. Menggunakan metode konstruksi lain yang lebih cepat.

Apabila metode pekerjaan yang sedang dilaksanakan kurang efisien, maka perubahan metode pelaksanaan pun bisa dilakukan sebagai solusi agar pengerjaan pekerjaan bisa lebih cepat dan sesuai dengan harapan.

\section{METODE PENELITIAN}

\section{Rancangan Penelitian}

Rancangan penelitian dalam penelitian ini sebagai berikut :

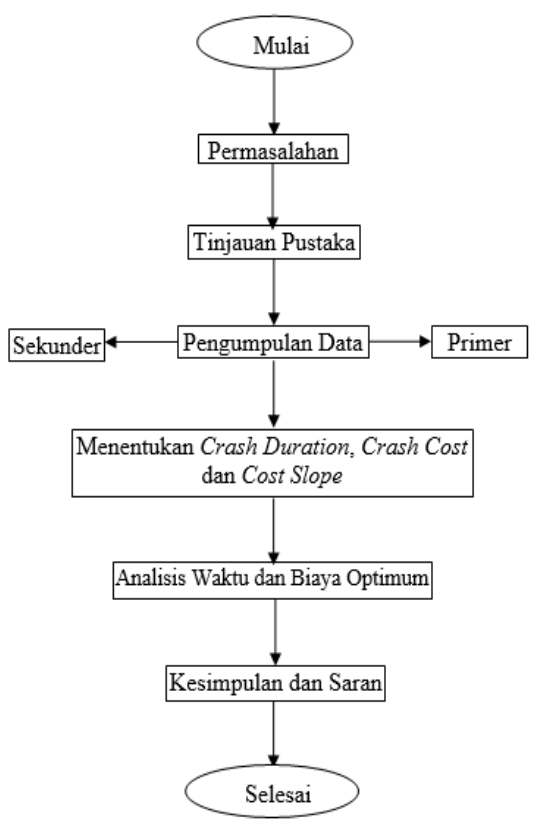

Gambar 3.1. Bagan Alir Penelitian

\section{Subyek Penelitian}

\section{Lokasi Penelitian}

Secara Geografis Provinsi Kalimantan Tengah terletak antara 0'45'LU- 3'30"LS dan 111'BT-116' BT diantara tiga provinsi tetangga yaitu Provinsi Kalimantan Barat,Provinsi Kalimantan Timur dan Provinsi Kalimantan Selatan dengan Luas Wilayah Kalimantan Tengah sebesar $153.564 \mathrm{Km} 2$ atau 8,04 persen dari total luas daratan.

Dengan sebelas sungai besar dan tidak kurang dari 33 sungai kecil/anak sungai, dan menjadi salah satu ciri khas Kalimantan Tengah.

Berdasarkan sensus Tahun 2010 ,memiliki populasi 2.202.599 jiwa, yang terdiri atas 1.147 .878 laki-laki dan 1.054.721 perempuan .Kalimantan Tengah mempunyai 13 kabupaten dan 1 kotamadya.

Salah satunya Pemba-ngunan Jembatan Sei Hanyu yang berada di Kecamatan Kapuas Hulu adalah Jembatan yang menghubungkan tiga Kabupaten Kota yaitu Kabupaten Gunung Mas ,Kabupaten Kapuas dan Kabupaten Murung Raya .

\section{Obyek Penelitian}

Obyek penelitian ini adalah pada Proyek Pembangunan Jembatan Sei Hanyu yang berada pada wilayah Kecamatan Kapuas Hulu Kabupaten Kapuas. 
Untuk lebih jelasnya dapat dilihat pada Peta Lokasi dibawah ini :

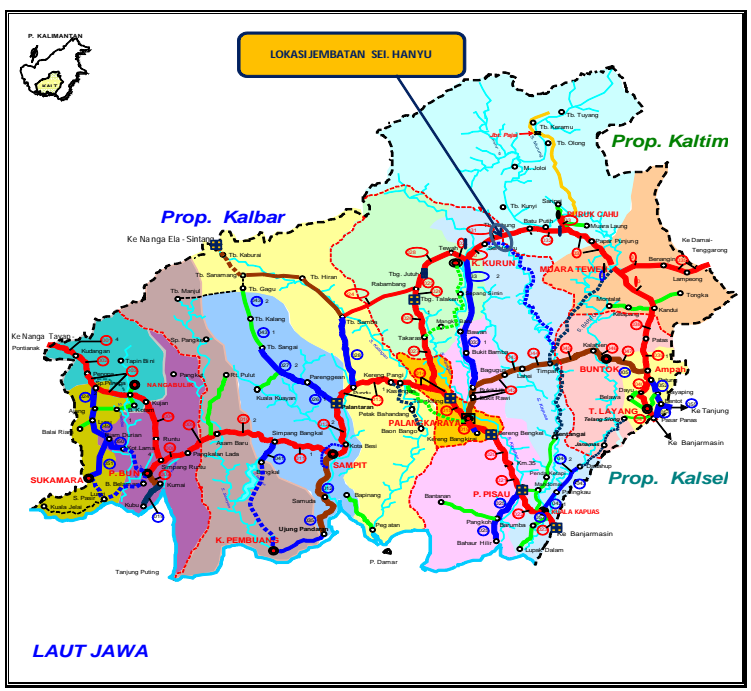

Gambar 3.2 Peta Lokasi Proyek.

\section{Instrumen Penelitian}

Data yang diperlukan untuk penelitian ini adalah dokumen laporan pelaksanaan dan spesifikasi teknik pelaksanaan, meliputi metode pelaksanaan yang digunakan dalam melaksanakan pekerjaan pelaksanaan, jumlah orang yang dipakai atau digunakan dalam pengerjaan dari tiap item pekerjaan, Time Schedule dan jumlah jam kerja yang terjadi dan sesuai dengan di lapangan, Gambar denah pelaksanaan serta gambar pelaksanaan lainnya yang berhubungan.

\section{Teknik Analisis Data}

1. Data primer

Data yang diperoleh dari Kontraktor PT. DEWANTO CIPTA PRATAMA maupun pengamatan sendiri dilapangan.

2. Data Sekunder

Data yang diperoleh dari perpustakaan dengan mempelajari buku-buku dan berbagai literatur yang berhubungan dengan topik yang dibahas yaitu Time Cost Trade Off (TCTO) kemudian dianalisa untuk tahap selanjutnya.

\section{Perhitungan Produktivitas Harian Normal}

Produktivitas harian normal dapat didefinisikan sebagai kemampuan untuk menyelesaikan pekerjaan dengan volume tertentu tiap harinya berdasarkan durasi normal tanpa adanya tambahan usaha atau alternatif percepatan. Secara umum produktivitas harian normal dihitung berdasarkan persamaan berikut:

$$
\text { Produktivitas Harian Normal }=\frac{\text { VolumePekerjaan }}{\text { Durasi Normal }}
$$

\section{Perhitungan Produktivitas Harian Percepatan}

Produktivitas harian percepatan diperoleh dari jumlah produktivitas harian normal dengan produktivitas pekerjaan saat jam lembur per hari. Penambahan jam kerja lembur sesuai peraturan yang berlaku dilakukan selama 3 jam per hari, sedangkan produktivitas pekerja jam lembur diasumsikan mengalami penurunan, dan hanya diperhitungkan sebesar $80 \%$ dari produktivitas jam kerja regular (Chusairi, 2015).

\section{Menentukan Crash Duration, Crash Cost dan Cost Slope}

Setelah diketahui besarnya produktivitas harian percepatan akibat jam lembur, maka langkah selanjutnya adalah menghitung durasi percepatan (crash duration) dan biaya langsung percepatan (crash cost). Perhitungan crash duration ini digunakan untuk mendapatkan batasan waktu maksimal suatu aktivitas mampu untuk dilakukan crashing (crashability), sedangkan perhitungan crash cost digunakan untuk mencari slope biaya (cost slope) masing-masing aktivitas.

\section{Analisis Waktu dan Biaya Optimum}

Setelah didapatkan rekapitulasi Crash Duration, Crash Cost dan Cost Slope, selanjutnya dilakukan analisis waktu dan biaya optimum melalui grafik hubungan waktu versus biaya.

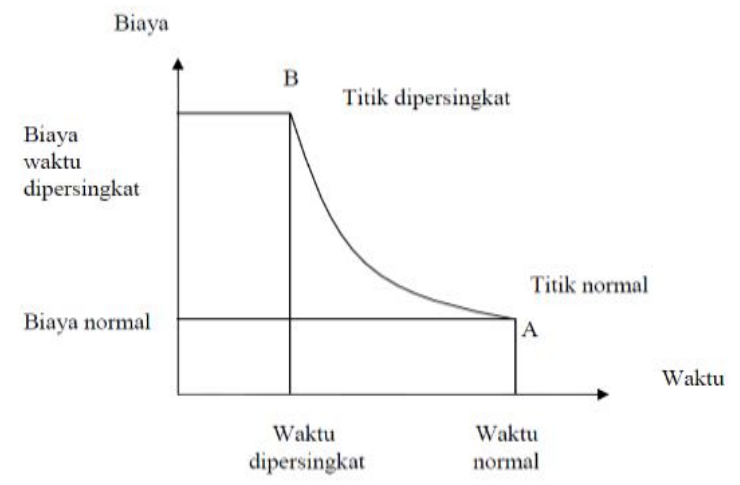

Gambar 3.3. Grafik Hubungan Waktu - Biaya Normal dan Dipersingkat 
Analisis Waktu Dan Biaya Dengan Metode Crash...Wateno ${ }^{(\mathbf{1})}$, Priyoto ${ }^{(\mathbf{2})}$, Uhad ${ }^{(\mathbf{3})}$

\section{ANALISIS DATA DAN PEMBAHASAN}

\section{Data Proyek}

\section{Data Umum Proyek}

Lokasi penelitian adalah Proyek Pembangunan Jembatan Sei Hanyu Kabupaten Kapuas, yang bertujuan untuk meningkatkan peranan jembatan, pengembangan wilayah yang menghubungkan pusat - pusat pertumbuhan dengan wilayah dalam pelayanan sistem jaringan primer, memperlancar hubungan tranportasi darat di Kabupaten Kapuas, serta memacu pertumbuhan ekonomi masyarakat berkat lancarnya distribusi barang dan jasa.

\section{Deskripsi Kontrak}

\section{Kontrak Multy Yers Contract (MYC) \\ Kontraktor Pelaksana $\quad$ : PT. DEWANTO CIPTA PRATAMA}

Konsultan Supervisi $\quad$ : PT. WIRAGUNA TANI

Nilai Kontrak Induk $\quad$ : Rp 58.141.500.000

Nomor Kontrak Induk : KU.08.08/KTRK/ SNVT.PJN.WIL II/PPK 12/XII/178

Tanggal Kontrak $\quad$ : 07 Desember 2011

Waktu Pelaksanaan : 845 Hari Kalender

Waktu Pemeliharaan : 540 Hari Kalender

\section{Data Pelaksanaan Proyek}

Data pelaksanaan proyek merupakan data RAB pekerjaan berupa uraian pekerjaan, satuan, kuantitas, harga satuan, jumlah harga dan bobot rencana proyek Pembangunan Jembatan Sei Hanyu Kabupaten Kapuas adalah sebagai berikut :
Tabel 4.1. RAB Pekerjaan pembangunan jembatan Sei Hanyu Kabupaten Kapuas

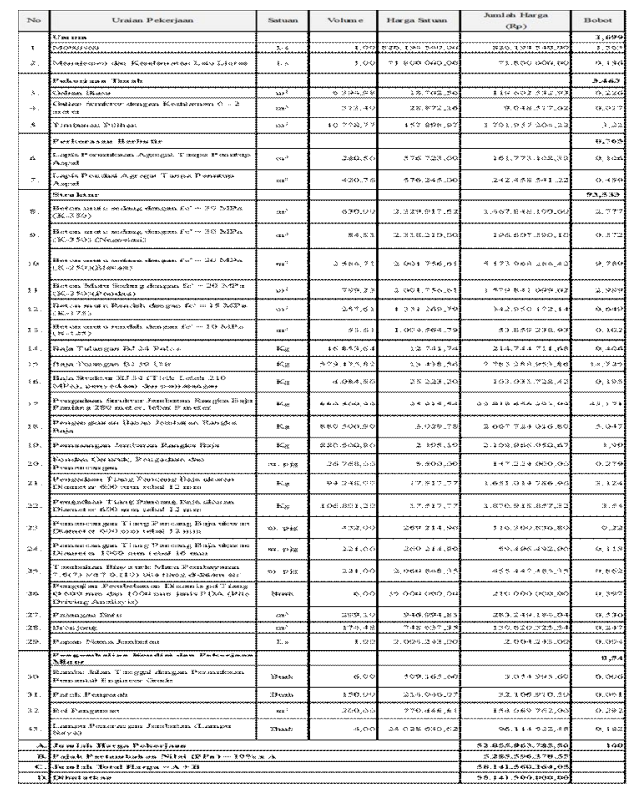

Dari tabel 4.1 didapatkan biaya pekerjaan yang paling dominan adalah pekerjaan struktur, dengan bobot pekerjaan 93,533\% dari keseluruhan biaya proyek.

Pada saat peninjauan di lapangan, ditemukan adanya keterlambatan dalam pelaksanaannya, yaitu sebesar 2,03\% dari kondisi rencana. Kumulatif Progress yang direncanakan hingga pada akhir Desember 2014 progress realisasinya hanya sebesar $97,97 \%$.

\subsection{Analisa Crashing Program}

Dalam mempercepat durasi proyek biasanya dilakukan pada pekerjaan-pekerjaan yang memiliki lintasan kritis. Karena kegiatan-kegiatan yang memberikan pengaruh besar pada proyek berada pada jalur kritis tersebut.

Adapun ketetapan rencana pada alternatif penambahan jam kerja ini adalah sebagai berikut :

1. Waktu kerja normal adalah 8 jam kerja per hari (08.00 - 17.00) dengan 1 jam istirahat (12.00 13.00), sedangkan kerja lembur dilakukan setelah waktu kerja normal selama 3 jam per hari $(18.30$ - 22.30). Dalam seminggu hanya dilakukan 6 hari kerja, yaitu Senin - Sabtu.

2. Menurut Keputusan Menteri Tenaga Kerja Nomor: KEP.102/MEN/VI/ 2004 pasal 11, upah 
untuk jam kerja (lembur) diperhitungkan sebagai berikut:

a. Untuk 1 jam kerja lembur pertama, upah yang harus dibayar adalah 1,5 kali upah sejam.

b. Untuk setiap jam kerja berikutnya, upah yang harus dibayarkan adalah 2 kali upah sejam.

3. Produktivitas untuk jam kerja lembur diperhitungkan sebesar $60 \%$ dari produktivitas normal

\section{Penentuan Lintasan Kritis (Critical Path)} adalah :

Langkah-langkah penentuan lintasan kritis

a. Pembuatan jadwal rencana kegiatan pekerjaan Pembangunan Jembatan Sei Hanyu Kabupaten Kapuas dengan Schedulle Diagram Batang untuk mendapatkan waktu normal dalam melaksanakan suatu kegiatan .Adapun Schedulle Diagram Batang tersebut terdapat pada Lampiran : Gambar 4.2

b. Waktu yang didapat dari Schedulle Diagram Batang dapat dibuat Microsoft Project

Tabel 4.2. Jadwal Pembangunan Jembatan Sei Hanyu Kabupaten Kapuas Dengan Microsoft Project

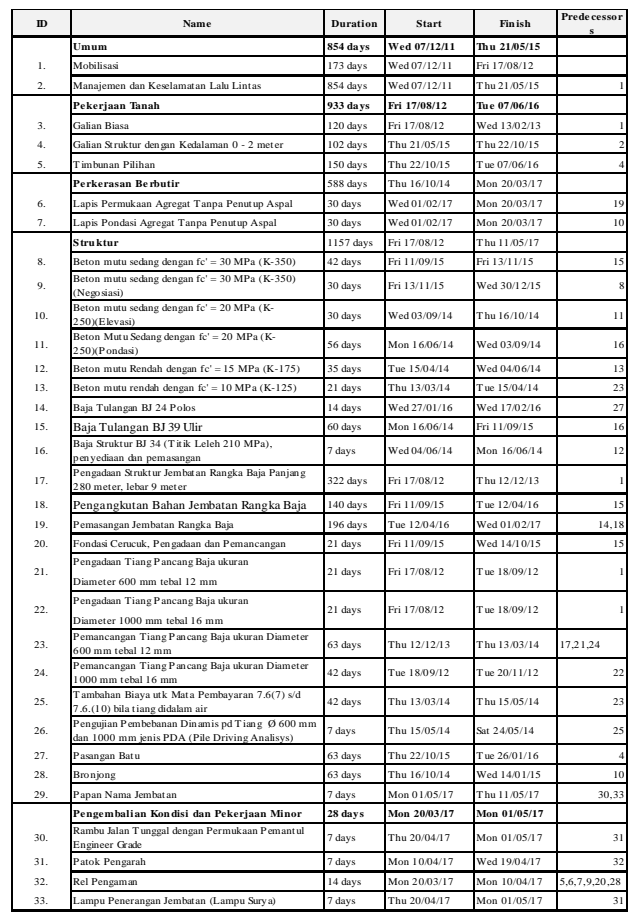

Keterangan: FS = Finish to Start

$$
\text { SS }=\text { Start to Start }
$$

c. Pembuatan diagram network dari jadwal kegiatan pekerjaan Pembangunan Jembatan Sei Hanyu Kabupaten Kapuas adalah sebagai berikut :

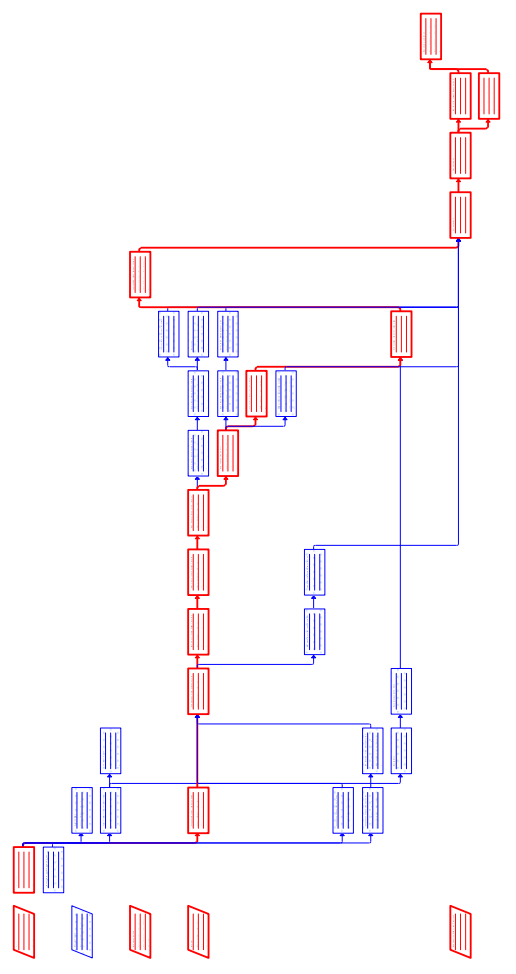

Gambar 4.2. Diagram Network Pekerjaan Pembangunan Jembatan Sei Hanyu Kabupaten Kapuas Dengan Microsoft Project.

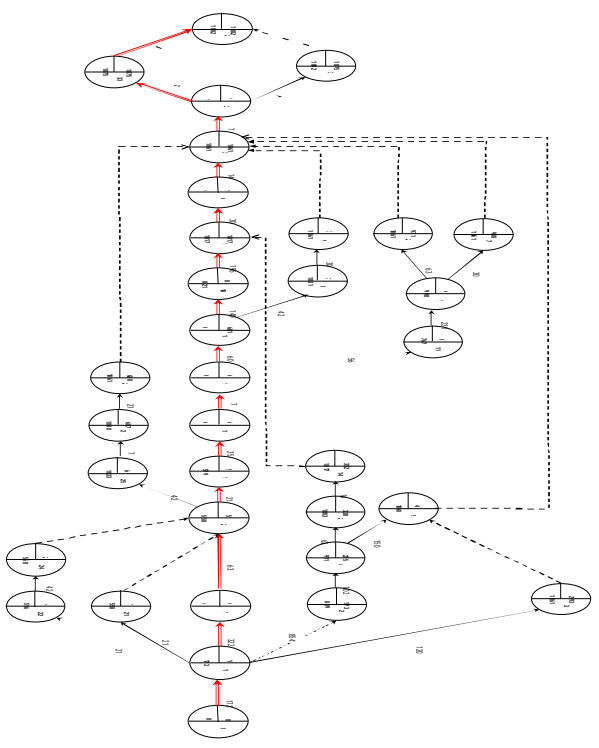


Analisis Waktu Dan Biaya Dengan Metode Crash... Wateno ${ }^{(\mathbf{1})}$, Priyoto ${ }^{(\mathbf{2})}$ Uhad $^{(\mathbf{3})}$

Dari tabel 4.2 dapat ditentukan waktu kegiatan dipercepat sebagai berikut:

Tabel 4.3. Kegiatan Pekerjaan Durasi Normal

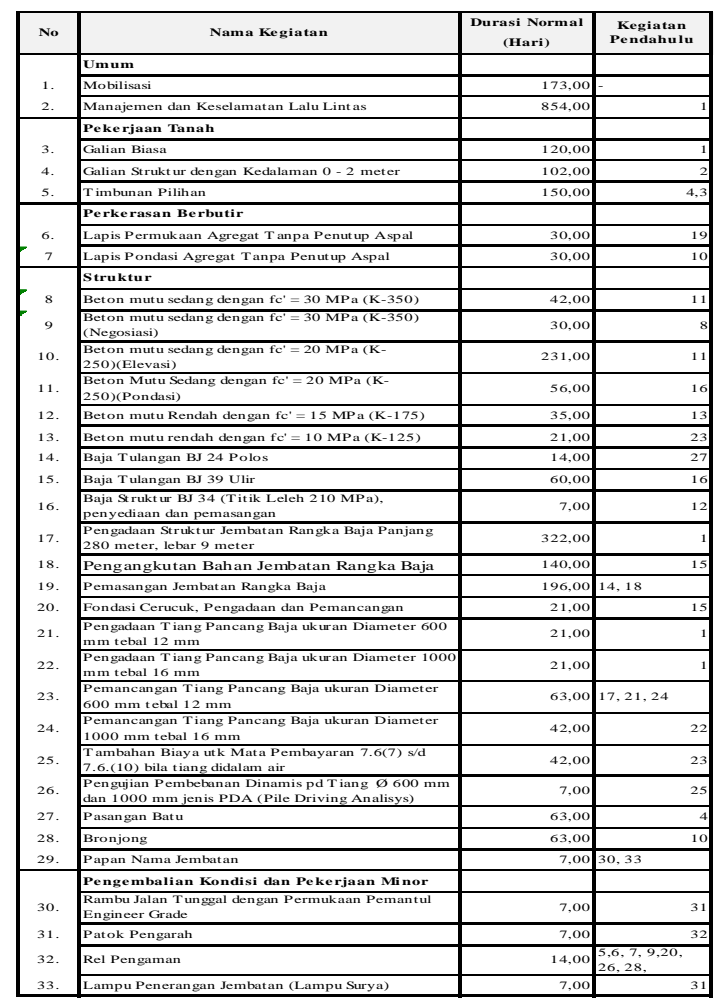

Sumber : Tabel 4.2

Dari tabel 4.3 tersebut dapat ditentukan lintasan kritis dengan menggunakan network planning sebagai berikut :

Tabel 4.4. Kegiatan Pekerjaan Kritis Pembangunan Jembatan (Durasi Normal).

\begin{tabular}{|c|c|c|c|c|c|c|c|}
\hline o. & Uraian Pekkejann & Salun & Volume & Hargas Satuan & $\begin{array}{c}\text { Jumlah Harga } \\
\quad(\mathrm{Rp})\end{array}$ & Bobat & Durssi (Hari) \\
\hline & Umum & & & & & & \\
\hline 1. & Motilisai & $\overline{L S}$ & & $826.194 .540,00$ & $826.194 .540,00$ & 1,563 & 173 \\
\hline \multirow{3}{*}{6.} & Perkerasan Berbutir & & & & & & \\
\hline & Lapisis Permukaan Aggegat Tanpa Penuw Apal & $\mathrm{m}^{3}$ & 280,5 & $576.723,00$ & $161.773 .108,39$ & 0,306 & 30 \\
\hline & Struktur & & & & & & \\
\hline 12. & Bcton Mutu rendala dengun $f c^{\prime}=15 \mathrm{Mpa}(\mathrm{K}-175)$ & $\mathrm{m}^{3}$ & 257,61 & 1.331.269,79 & $342.950 .172,14$ & 0,649 & 35 \\
\hline 13. & Becon Mutu rendala dengan fé $=10 \mathrm{Mpa}(\mathrm{K}-125)$ & $\mathrm{m}^{3}$ & 53,61 & $1.004 .564,79$ & $53.859 .238,93$ & 0,102 & 21 \\
\hline 15. & Baja Tulangan BJ39 Ulir & $\mathrm{Kg}$ & $579.175,82$ & $13.438,56$ & 7.788 .288 .953 .86 & 14,725 & 60 \\
\hline 16. & 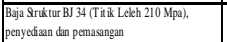 & $\mathrm{Kg}$ & $4.084,80$ & $25.223,20$ & $103.031 .728,42$ & 0,195 & \\
\hline 17. & 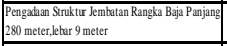 & $\mathrm{Kg}$ & 880.500900 & $25.915,54$ & $22.818 .656 .293,99$ & 43,171 & 322 \\
\hline 18. & Penganglutuan Bahan Jembatan Rangka Baja & $\mathrm{Kg}$ & 880.500900 & $3.029,78$ & $2.667 .724 .016,80$ & 5,047 & 140 \\
\hline 19. & Pemaxangan Jembatan Rangka Baja & $\mathrm{Kg}$ & 880.500 .90 & $2.395,19$ & $2.108 .966 .950,67$ & 3,99 & 196 \\
\hline \multirow[t]{2}{*}{23.} & \begin{tabular}{|l|} 
Pemancanganan Tiang Parcang Baja Vkuran \\
Diamceter $600 \mathrm{~mm}$ tetal $12 \mathrm{~mm}$
\end{tabular} & m.Pig & 432 & $269.214,90$ & $116.300 .836,80$ & 0,22 & 63 \\
\hline & Pengembalian Kondisi dan Pekerjaan Minor & & & & & & \\
\hline 29. & \begin{tabular}{|l} 
Papan Nama Jembetann \\
\end{tabular} & 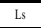 & & $2,004.243,00$ & $2.004 .243,00$ & 0,004 & \\
\hline 31. & Patok Pengarah & Buah & 150 & $214.046,07$ & $32.106 .910,50$ & 0,061 & \\
\hline 32. & Rel Pengaman & $\mathrm{m}^{1}$ & 200 & $770.448,81$ & $154.089 .762,00$ & 0,292 & 14 \\
\hline \multirow[t]{2}{*}{33.} & Lampu Penerangan Jembatan (Lampu Sirya) & Buah & & $24.028 .630,62$ & $96.114 .522,48$ & 0,182 & 7 \\
\hline & Total & & & & & & 1.082 \\
\hline
\end{tabular}

Gambar 4.3. Diagram Network (Durasi Normal) Pekerjaan Pembangunan Jembatan Sei Hanyu Kabupaten Kapuas

Kegiatan Pekerjaan Pembangunan Jembatan yang tidak boleh ditunda berada pada (Lintasan Kritis) yang terdapat pada Gambar 4.3 Diagram Network (Durasi Normal ) adalah sebagai berikut :

\section{Perhitungan Produktivitas Harian, Normal dan Percepatan}

Produktivitas harian percepatan diperoleh dari jumlah produktivitas harian normal dengan produktivitas pekerjaan saat jam lembur per hari. Penambahan jam kerja lembur sesuai Peraturan yang berlaku dilakukan selama 3 jam per hari, sedangkan produktivitas pekerja jam lembur diasumsikan mengalami penurunan, dan hanya diperhitungkan sebesar $80 \%$ dari produktivitas jam kerja regular.

Langkah-langkah perhitungan produktivitas harian percepatan pekerjaan kritis adalah sebagai berikut :
a. Menghitung volume pekerjaan
b. Menghitung durasi normal
c. Menghitung produktivitas harian normal
d. Produktivitas normal/jam
e. Produktivitas jam lembur
f. Produktivitas harian percepatan

Contoh : 1

Perhitungan produktivitas harian normal pada Lapis Permukaan Agregat tanpa Penutup Aspal:

a. Volume pekerjaan $=280,50 \mathrm{~m}^{3}$

b. Harga Satuan = Rp. $576.723,00 / \mathrm{m}^{3}$

d. Durasi normal $=30$ hari

e. Produktivitas harian normal = $\quad \mathrm{a} / \mathrm{d}$

$=\frac{280,50 \mathrm{~m}^{3}}{30 \text { Hari }}=9,350 \mathrm{~m}^{3}$ hari

f. Produktivitas normal $/ \mathrm{jam}=\mathrm{e} / 8=$ $\frac{9,350 \mathrm{~m}^{3} / \text { hari }}{8 \mathrm{jam} / \mathrm{hari}}=1,169 \mathrm{~m}^{3} / \mathrm{jam}$

g. Produktivitas jam lembur $=3 \times$ f x 0,80

$$
\begin{aligned}
& =3 \times 1,169 \times 0,80 \\
& =2,8056 \mathrm{~m}^{3} / \mathrm{jam}
\end{aligned}
$$

h. Produktivitas harian percepatan

$$
=(\mathrm{f}+\mathrm{g}) \times 8
$$


Analisis Waktu Dan Biaya Dengan Metode Crash...Wateno ${ }^{(\mathbf{1})}$, Priyoto ${ }^{(\mathbf{2})}$, Uhad ${ }^{(\mathbf{3})}$

$$
\begin{aligned}
& =(1,169+2,8056) \times 8 \\
& =31,7968 \mathrm{~m}^{3} / \text { hari }
\end{aligned}
$$

Dengan cara yang sama perhitungan produktivitas harian, normal dan percepatan adalah sebagai berikut :

Tabel 4.5. Produktivitas Harian Percepatan Pekerjaan Kritis

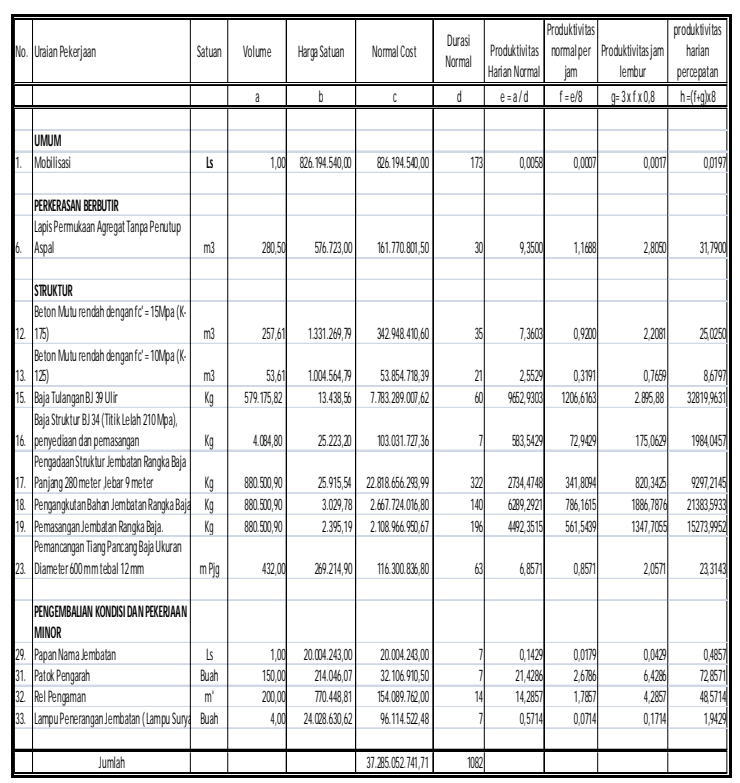

Perhitungan Crash Duration, Crash Cost, dan Cost Slope

Setelah diketahui besarnya produktivitas harian percepatan pekerjaan kritis, maka langkah selanjutnya adalah menghitung durasi percepatan (crash duration) dan biaya langsung percepatan (crash cost). Perhitungan crash duration ini digunakan untuk mendapatkan batasan waktu maksimal suatu aktivitas mampu untuk dilakukan crashing (crashability), sedangkan perhitungan crash cost digunakan untuk mencari slope biaya (cost slope) masing-masing aktivitas.

Untuk menentukan Crash Cost dapat dilakukan dengan langkah-langkah berikut:

a. Menghitung upah kerja harian normal, yaitu produktivitas harian $\mathrm{x}$ harga satuan upah kerja

b. Menghitung upah kerja normal, yaitu produktivitas per jam x harga satuan upah kerja

c. Menghitung upah kerja lembur per hari:

1. Untuk 3 jam lembur $=(1,5 \mathrm{x}$ upah sejam normal $)+2(2 \times$ upah sejam normal $)$
2. Untuk 4 jam lembur $=(1,5 \times$ upah sejam normal $)+3(2 \times$ upah sejam normal $)$

d. Menghitung Crash Cost per hari, yaitu upah harian + upah kerja lembur per hari

d. Menghitung Crash Cost total, yaitu Crash Cost per hari + Crash Duration

Contoh : 1

Perhitungan crash duration, crash cost, dan cost slope untuk Pekerjaan Lapis Permukaan Agregat tanpa Penutup Aspal sebagai berikut:

a. Volume pekerjaan $=280,50 \mathrm{~m}^{3}$

b. Durasi Percepatan $=29$ Hari

c. Normal cost $=\mathrm{Rp} 161.770 .801,50$

d. Durasi normal $=30$ hari

e. Produktivitas normal/hari= $\mathrm{m}^{3} / \mathrm{jam}$

f. Produktivitas normal/jam = $\quad 1,1688$ $\mathrm{m}^{3} / \mathrm{jam}$

g. Produktivitas Lembur $/ \mathrm{Jam}=2,8050$ $\mathrm{m} 3 / \mathrm{jam}$

h. Produktivitas harian percepatan $=31,7968$ $\mathrm{m}^{3} /$ hari

i. Crash duration =

$\mathrm{b}-\left(\frac{\mathrm{a}}{\mathrm{h}} / 8\right)=30-\left(\frac{280,50 \mathrm{~m}^{3}}{31,7968 \mathrm{~m}^{3} / \text { hari }} / 8\right)=29$ hari $\mathrm{j}$.

Upah normal/jam $=\mathrm{d} \times \mathrm{g}$ $=\operatorname{Rp} 576.723,00 / \mathrm{m}^{3} \times 1,1687 \mathrm{~m}^{3} / \mathrm{jam}$ $=\operatorname{Rp} 674.016,17 / \mathrm{jam}$

k. Upah normal/hari $=\mathrm{j}$ x 8 $=\operatorname{Rp} 674.016,17 / \mathrm{jam} \times 8$ $=\operatorname{Rp~5.392.129,361/hari~}$

1. Upah 3 jam lembur/ hari $\quad=(1,5 \times \mathrm{j})$ $+2 \times(2 \times j)$

$=(1,5 \times \operatorname{Rp} 674.016,17)+2 \mathrm{x}$

(2x Rp 674.016,17)

$=\mathrm{Rp} 3.707 .088,935 / \mathrm{hari}$

m. Cost Upah Percepatan/hari $=(\mathrm{c}+\mathrm{l}) / \mathrm{i}$

$=($ Rp. 161.770.801,50 + Rp.3.707.88,935) 129

$=$ Rp.5.706.139,62/hari

n. Cost upah/hari $=(\mathrm{c}+\mathrm{m})$

$=$ Rp161.770.801,50/hari $\quad+\quad \mathrm{Rp}$ 5.706.139,62/hari

$=\mathrm{Rp} 167.476 .941,12$ /hari

o. Cost bahan = a x e $=280,50 \mathrm{~m}^{3} \times \mathrm{Rp} 0,00 / \mathrm{m}^{3}$ $=\operatorname{Rp} 0,00$

p. Cost alat $=\mathrm{axf}$ $=280,50 \mathrm{~m}^{3} \times \mathrm{Rp} 0,00 / \mathrm{m}^{3}$

$=\operatorname{Rp} 0,00$

q. Crash cost $=\mathrm{n}+\mathrm{o}+\mathrm{p}$ $=\operatorname{Rp} 167.476 .941,12+\operatorname{Rp~0,00+~}$ 
Analisis Waktu Dan Biaya Dengan Metode Crash...Wateno ${ }^{(\mathbf{1})}$, Priyoto ${ }^{(\mathbf{2})}$, Uhad ${ }^{(\mathbf{3})}$

$$
\begin{aligned}
& \operatorname{Rp} 0,00 \\
= & \operatorname{Rp~} 167.476 .941,12
\end{aligned}
$$

r. Cost slope $=\frac{\mathrm{q}-\mathrm{c}}{\mathrm{b}-\mathrm{i}}=$

$=\underline{\text { Rp167.476.94,12-Rp161.770.80,50 }}$

$=\operatorname{Rp} 5.706 .139,62 /$ hari

Dengan cara yang sama perhitungan Crash Duration, Crash Cost, dan Cost Slope kegiatan kritis dapat diketahui.

Pekerjaan Durasi Normal dan Durasi Crash adalah sebagai berikut :

Tabel 4.7. Kegiatan Pekerjaan Durasi Normal dan Durasi Crash

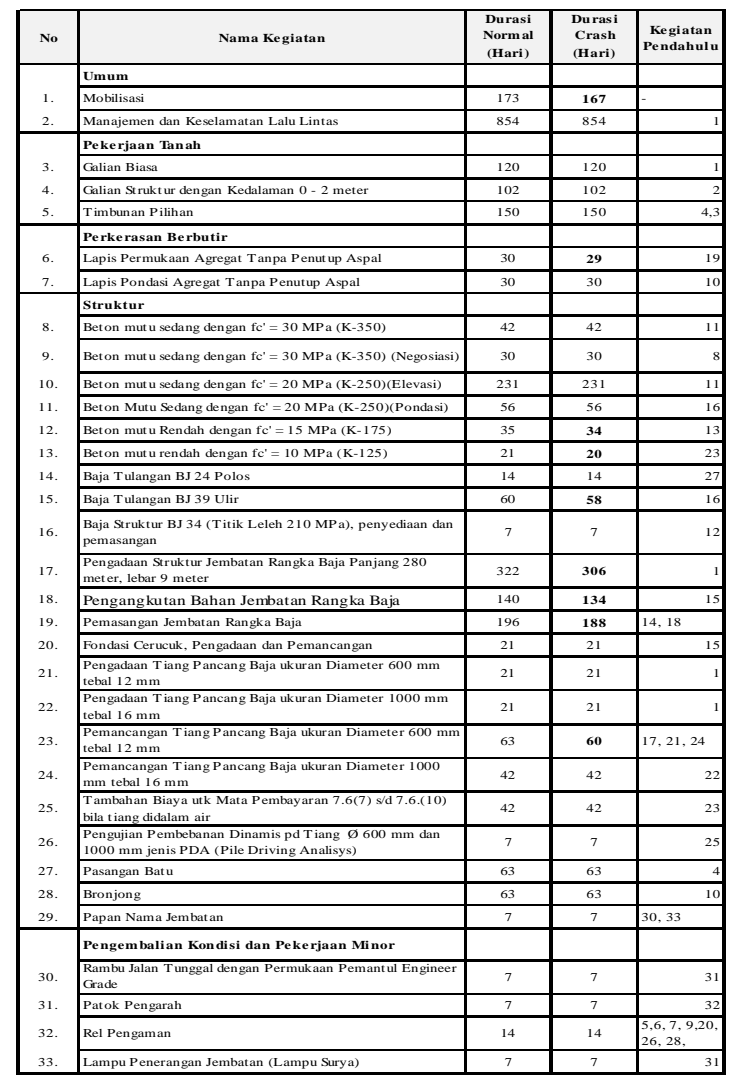

Pada tabel 4.7 dapat dibuat diagram network setelah dilakukan perhitungan maju dan perhitungan mundur, maka waktu yang diperlukan untuk menyelesaikan pekerjaan Pembangunan Jembatan Sei Hanyu Kabupaten Kapuas adalah 1038 hari kalender (148 minggu), dapat dipercepat 44 hari dari perencanaan semula 1.082 hari kalender (155 minggu), adapun diagram network adalah sebagai berikut :

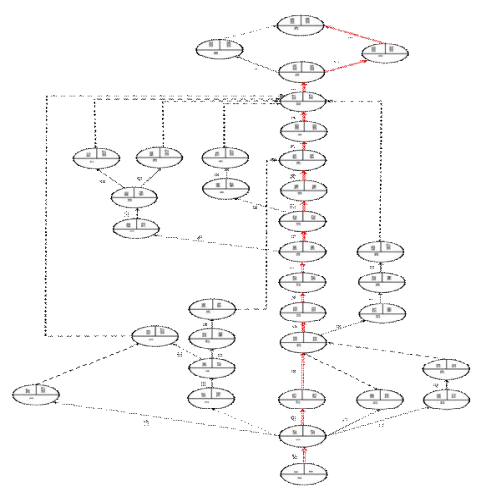

Gambar 4.4. Diagram Network (Durasi Percepatan) Pekerjaan Pembangunan Jembatan Sei Hanyu Kabupaten Kapuas.

Dari Tabel 4.6. Perhitungan Crash duration, Crash Cost, dapat dibuat Tabel 4.7 Cost Normal dan Cost Percepatan

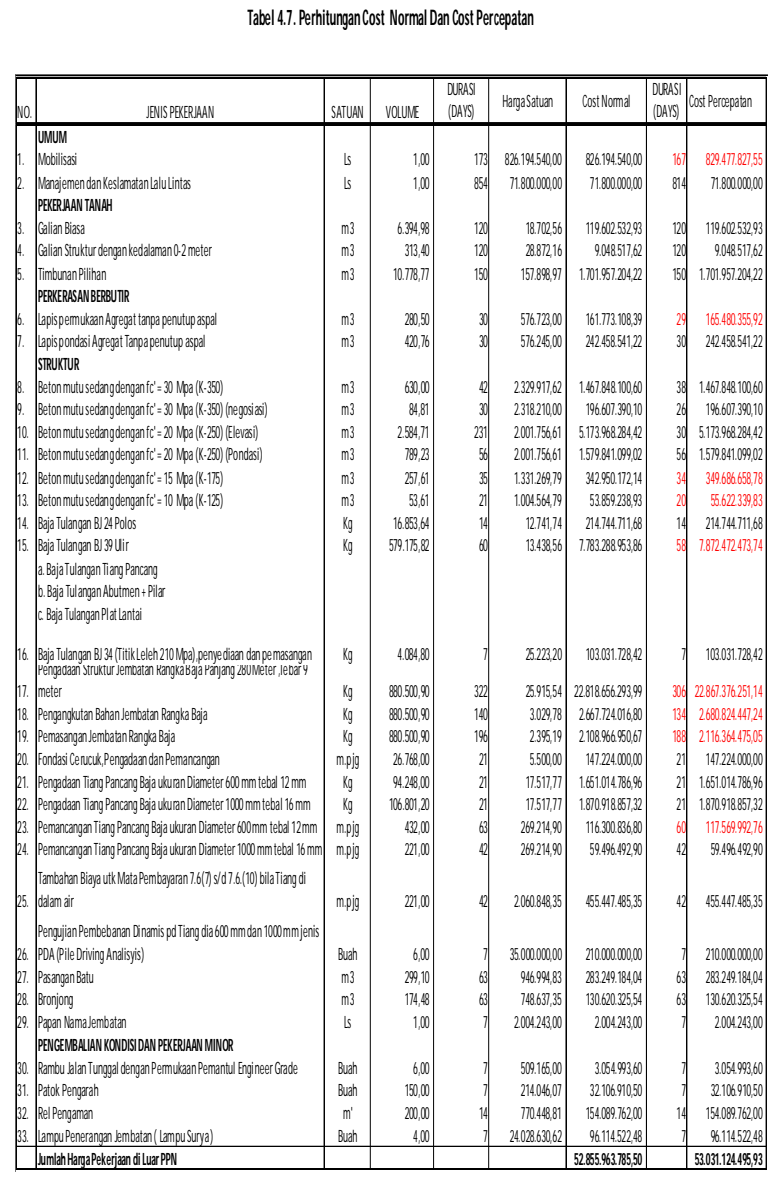

\section{Analisis Waktu dan Biaya Optimum}

Setelah dilakukan Perhitungan Crash duration, Crash Cost, dan Cost Slope, kemudian 
Analisis Waktu Dan Biaya Dengan Metode Crash...Wateno ${ }^{(\mathbf{1})}$, Priyoto ${ }^{(\mathbf{2})}$, Uhad ${ }^{(\mathbf{3})}$

dilakukan analisis waktu dan biaya optimum setelah percepatan sebagai berikut :

\begin{tabular}{|c|c|c|c|c|c|c|}
\hline \multicolumn{3}{|c|}{ Sehelum Perrepatan } & \multicolumn{2}{|c|}{ Setelah Perrepatan } & \multicolumn{2}{|r|}{ Pen bahan } \\
\hline $\begin{array}{c}\text { Total Biaya } \\
\text { Proỵek Normal }\end{array}$ & $\begin{array}{l}\text { Durasi } \\
\text { Normal }\end{array}$ & $\begin{array}{c}\text { Biaga Normal Pada } \\
\text { Pekerjaan Kritis }\end{array}$ & $\begin{array}{c}\text { Durasi } \\
\text { Percepatan }\end{array}$ & $\begin{array}{c}\text { Biaya Percepatan } \\
\text { Pada Pekerjan } \\
\text { Kritis }\end{array}$ & $\mid \begin{array}{c}\text { Selisish } \\
\text { Durasi } \\
\text { Percepatan }\end{array}$ & $\begin{array}{c}\text { Peunambahan Biaya } \\
\text { Alkibat Durasi } \\
\text { Percepatan }\end{array}$ \\
\hline a & b & c & $d$ & e & $f=b \cdot d$ & $g=e-\varepsilon$ \\
\hline 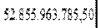 & 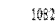 & 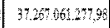 & 称视 & $3 \%$ & at & 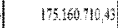 \\
\hline
\end{tabular}

Tabel 4.8. Tabel Perubahan Waktu dan Biaya Akibat Percepatan

Hasil dari perhitungan diatas dapat diketahui biaya proyek sebagai berikut :

1. Rencana Anggaran biaya proyek dengan waktu 1082 hari sebesar $:=$ Rp. 52.855.963.785,50

2. Biaya percepatan dengan penambahan tenaga kerja sebagai berikut :

Biaya percepatan pada pekerjaan Kritis Biaya Normal pada pekerjaan kritis $=\mathbf{R p}$. 175.160.710,43

3. Keuntungan Kontraktor sebesar $15 \%$

$=$ Rp. 52.855.963.785,50 x $15 \%$

$=$ Rp. 7.928.394.567,83

4. Total biaya setelah dikurangi keuntungan kontraktor sebesar $15 \%$

$=$ Rp. 52.855.963.785,50 - Rp.

7.928.394.567,83

= Rp. 44.927.569.217,68

5. Keuntungan kontraktor setelah percepatan : $=$ Rp. 7.928.394.567,83 - Rp. 175.160.710,43

= Rp. 7.753.233.857,26

6. Biaya proyek dengan penambahan tenaga kerja adalah :

Rencana anggaran proyek + biaya penambahan tenaga kerja

$=$ Rp. 44.927.569.217,68 + Rp. 175.160.710,43

= Rp. 45.102.729.928,11

Dengan demikian hubungan antara biaya dan waktu untuk menyelesaikan percepatan pekerjaan Pembangunan Jembatan Sei Hanyu Kabupaten Kapuas digambarkan sebagai berikut :

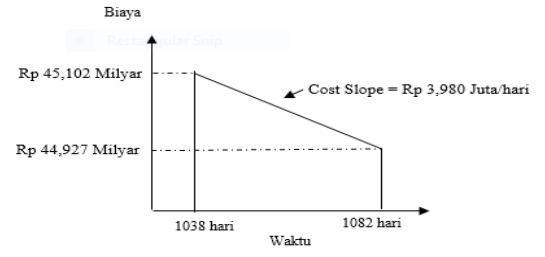

Gambar 4.5. Hubungan Antara Waktu dan Biaya pekerjaan Pembangunan Jembatan Sei Hanyu

Kabupaten Kapuas Setelah Dipercepat

\section{KESIMPULAN DAN SARAN}

\section{Kesimpulan}

Sesuai dengan tujuan penelitian dan hasil pembahasan, maka dapat disimpulkan bahwa:

1. Waktu yang diperlukan untuk mempercepat pelaksanaan pembangunan jembatan Sei Hanyu Kabupaten Kapuas selama 1038 hari kalender (148 minggu), dapat dipercepat 44 hari dari perencanaan semula 1082 hari kalender (155 minggu).

2. Dengan adanya percepatan penyelesaian pembangunan jembatan Sei Hanyu Kabupaten Kapuas diperlukan tambahan biaya sebesar Rp175.160.710,43 dengan penambahan biaya (cost slope) sebesar Rp3.980.925,24 per hari selama 44 hari, sehingga biaya optimal yang diperlukan untuk mempercepat pelaksanaan pembangunan jembatan Sei Hanyu Kabupaten Kapuas adalah sebesar Rp 45.102.729.928,11 yang semula direncanakan sebesar Rp 44.927.569.217,68. Sehingga terjadi penambahan biaya akibat percepatan pelaksanaan sebesar $=0,390 \%$ dari biaya yang direncanakan. Dan Keuntungan Kontraktor Pelaksana sebesar Rp. 7.753.233.857,26 atau $0,172 \%$.

\section{Saran}

Saran dari penelitian yang perlu adalah sebagai berikut:

1. Hasil durasi dan biaya optimum yang diperoleh dari analisis Crashing ini dapat dipertimbangkan penerapannya dalam pelaksanaan proyek. Hal ini dikarenakan hasil optimasi waktu dan biaya menunjukkan durasi pelaksanaan yang lebih singkat akan membutuhkan biaya pelaksanaan lebih besar dibandingkan kondisi durasi dan biaya normal, akan tetapi tidak membuat cost kontraktor rugi.

Sehingga hal ini tentu sangat bermanfaat bagi kontraktor dalam mengendalikan efisiensi waktu dan biaya proyek.

2. Penelitian tentang optimasi waktu dan biaya proyek dengan metode Crashing ini dapat dikembangkan lebih lanjut dengan menggunakan alternatif percepatan lain seperti, penambahan tenaga kerja, pemakaian sistem kerja shift, atau penggunaan metode pelaksanaan yang lebih efektif, yang diharapkan dapat memberi hasil yang lebih optimal terkait waktu dan biaya pelaksanaan proyek. 
Analisis Waktu Dan Biaya Dengan Metode Crash...Wateno ${ }^{(\mathbf{1})}$, Priyoto ${ }^{(\mathbf{2})}$, Uhad ${ }^{(\mathbf{3})}$

\section{DAFTAR PUSTAKA}

Ali. Tubagus Haedar, 2007, Prinsip-prinsip Network Planning, Penerbit Gramedia, Jakarta.

Badri. Sofyan. 1997, Dasar-Dasar Network Planning, Penerbit Rineka Cipta, Jakarta.

Buluatie. Nurhadinata, 2013, Optimalisasi Biaya dan Waktu dengan Metode Time Cost Trade Off pada Proyek Revitalisasi Gedung BPS Kota Gorontalo, Jurnal Ilmiah Teknik Sipil Vol.1, No.1, Universitas Negeri Gorontalo, Gorontalo.

Chusairi. Moch.. Mas Suryanto HS, 2015, Studi Optimasi Waktu Dan Biaya Dengan Metode Time Cost Trade Off Pada Proyek Pembangunan Gedung Tipe B Smpn Baru Siwalankerto, Rekayasa Teknik Sipil Vol 2 Nomer 2/rekat/15 (2015), 09 - 15.

Dipohusodo. Istimawan. 1996, Manajemen Proyek Dan Konstruksi Jilid I, Penerbit Kanisius, Jakarta.

Dipohusodo. Istimawan. 1996, Manajemen Proyek Dan Konstruksi Jilid II, Penerbit Kanisius, Jakarta.

Ervianto. Wulfram I, 2002, Manajemen Proyek Konstruksi, ANDI, Yogyakarta.

Frederika. Ariany, 2010, Analisis Percepatan Pelaksanaan dengan Menambah Jam Kerja Optimum pada Proyek Konstruksi, Jurnal Ilmiah Teknik Sipil Vol.14, No.2.

Gunawan Rudy, 1987, Tabel Profil Konstruksi Baja, Kanisius Edisi Revisi.

Kusrianto. Adi, 2007, Pengantar Desain Komunikasi Visual, Penerbit Andi, Yogyakarta.

Leach. L.P., 2000, Critical Chain Project Management. Artech House, Boston.
Lumbanbatu. Jevri Krisanto, Syahrizal, 2013, Akselerasi Durasi Proyek Pada Pembangunan Gedung Sekolah Yayasan Pelita Bangsa Yang Berlokasi di Jl.Iskandar Muda Medan, Departemen Teknik Sipil, Universitas Sumatera Utara, Medan

Pamungkas. Rita Nawangsari \& Hidayat. Rizki Taufik, 2011, Analisis Time Cost Trade Off Pada Proyek Konstruksi, Universitas Diponegoro, Semarang.

Santosa. Budi. 1997. Manajemen Proyek, Guna Widya, Jakarta.

Santosa. Budi, 2003, Manajemen Proyek, Guna Widya, Surabaya.

Soeharto. Iman, 1999, Manajemen Proyek (Dari Konseptual sampai Operasional), Erlangga Jakarta.

Soeharto. Imam, 2005. Manajemen Konstruksi, Penerbit Bina Ilmu, Jakarta.

Sudharta. Teguh Arifmawan, 2011, Optimasi Waktu Pelaksanaan Proyek Konstruksi dengan Penambahan Jam Kerja (Studi Kasus: Hotel Penin Sula Bay Resort). Jurnal Ilmiah Teknik Sipil, Universitas Udayana, Denpasar.

Wateno Oetomo , 2014 , Materi Kuliah Manajemen Proyek Konstruksi

Yasin, Makmun dan Akhmad, 2003, Pengaruh Investasi dan Tenaga Kerja terhadap PDB Sektor Pertanian, Kajian Ekonomi dan Keuangan, Vol. 7, No. 3 Sept. 2003.

1987, Pedoman Prencanaan Pembebanan Jembatan Jalan Raya, Badan Penerbit pekerjaan Umum, Jakarta. 